\title{
Destabilization of a gas in a looped tube with a temperature gradient
}

\author{
学 ○西川 晃平（阪大院基工） 正 杉本 信正（阪大院基工）
}

Kohei NISHIKAWA, Osaka University, 1-3, Machikaneyama, Toyonaka, Osaka Nobumasa SUGIMOTO, Osaka University

1. 緒言 管路内の気体に対して壁面に温度勾配を与えると， 粘性や熱伝導性による搪散効果によって気体が不安定化するこ とがある. なお，浮力は考えていない，不安定化すると気体に 圧力変動, すなわち音が発生するので,この現象は熱音響現象 と㭔ばれている. 最近ではループ管路内の気体の自励振動を用 いた熱機関が考案されているが, 研究は実験が先行し理論的に は不安定化の臨界条件が求められている段階にある.

臨界条件はUeda \& Kato ${ }^{1)}$ にっって温度比と管径の間の関係 として求められている.これは実験で用いられる細管を束ねた スタックを挿入した管路を想定している．この場合でも拡散層 が薄い場合にはこれまで展開してきた境界層理論 ${ }^{2)}$ が適用でき るのではないかと考えられる，そこで本研究では，境界層理論 によって不安定化とその後の発展を数値シミュレーションし， エネルギ一増幅する様子と管路内の音場の定量化を行う.

\section{2. 計算モデルと基礎方程式}

図 1 に計算モデルの概略図 を示す. 座標 $x$ を管軸に沿って 定義し， $x=-L$ と $x=L$ は同じ 位置を表す， $x=0$ にスタック の中心を設定し, 孔の半径は $r_{\text {stack }}$ で, スタックの長さは $L_{\text {stack }}$ である. また, スタック

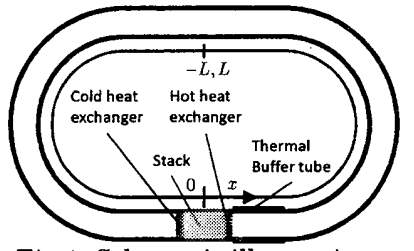

Fig.1. Schematic illustration of a looped tube with a stack.
の壁の厚さを無視することによって，スタック内の流管をスタ ック外部のループ管にも搪張する. ループを取り巻くこの流管 に対しては，スタック内では拡散効果を考慮するが，スタック 外ではレイノルズ数が十分に大きいため粘性や熱伝導性を無視 した平面波を仮定する．スタック内の気体に対しては境界層理 論を適用し，壁面近傍の境界層とその外部の主流部に分けて取 り扱う．スタック内の流管では，基礎方程式として，主流部に 対する連続の式, 運動方程式, エネルギー式, 状態方程式を断 面平均した方程式を用い，境界層外縁での内向き法線速度と主 流部速度と圧力の関係を別途与える.

3. 管壁の温度分布と計算条件 ループ管の管壁に沿って温度 分布 $T_{e}(x)$ を与える. $T_{e}(x)$ はスタック内と，バッファ領域と呼 ばれる高温部 $T_{H}$ と低温（室温）部 $T_{C}$ との間を除いて一定値 $\left(T_{e} / T_{C}=1\right)$ とする. スタック内では, $T_{e}(x)$ は $T_{C}$ から $T_{H}$ まで 直線的に増加し, バッファ領域では, $T_{e}(x)=\left(n T_{C}-T_{C}\right)$ $\exp \left[-\left(x-x_{b}\right) / R\right]+T_{C}$ で近似する.ここで， $n$ は室温に対する 高温部の温度比, $x_{b}$ はバッファ領域の開始位置, $R$ はバッファ 領域の幅である.

初期条件として, 流速の節がスタックの中心部にある正弦波 の擋乱を与え, 超過圧をゼロとする. 空気を想定し, 值径 $20 \mathrm{~mm}$ のループ管で周長 $2 L=2.8 \mathrm{~m}$, スタック長さ $L_{\text {stack }}=35 \mathrm{~mm}$ とし た. 数值計算はクランク・ニコルソン法, 修正シンプソン公式, 3 次精度の風上差分を用いた.

4. シミュレーション結果 まず，スタックの孔の半径を $r_{\text {stack }}=1.0 \mathrm{~mm}$, バッファ領域の幅を $R=0.15 \mathrm{~m}$ として温度比を
変化させ,位置 $x=-L / 2$ における流速の時間発展を計算した結 果を図 2 に示す．温度比が $n=1.3$ において中立振動しているの がわかる. さらに温度比 $n=1.4$ のときの時間 $t=0 \sim T \quad(n=0$ で の線形音波の周回周期を $T$ とした）における流速の空間分布を $1 / 8 T$ 毎に出力し，重ねて描いたものを図 $3(\mathrm{a})$ に示す。図 $3(\mathrm{~b})$ はさらに時間が進んだ $t=20 \sim 21 T$ を示しており, 位相が $x$ 軸に 対して正の方向に少しずれた位置でとどまり振動している．次 に図 4 (a)のように $\pi / 2$ だけ初期位相をずらして擋乱を与える と時間が経過するにつれて図 $4(\mathrm{~b})$ に示すような過渡的な位相を 経て，t=49 50T のとき図4(c)で示す位相となった.これは図 3 (b)に近い結果である.

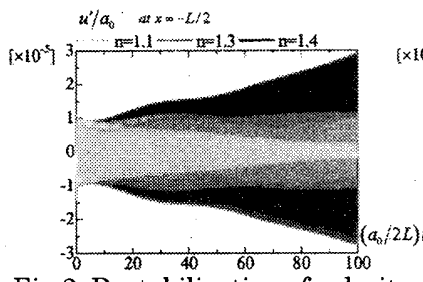

Fig.2. Destabilization of velocity

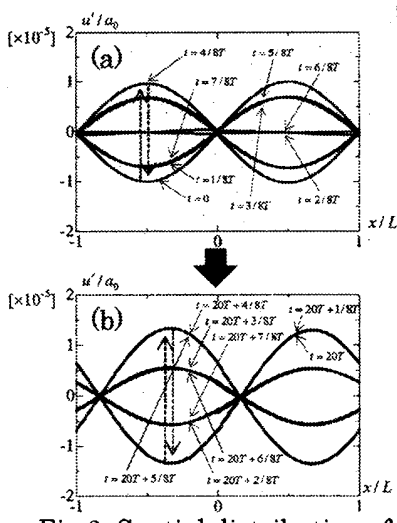

Fig.3. Spatial distribution of the axial velocity (a) $t=0 \sim T$ (b) $t=20 \sim 21 T$
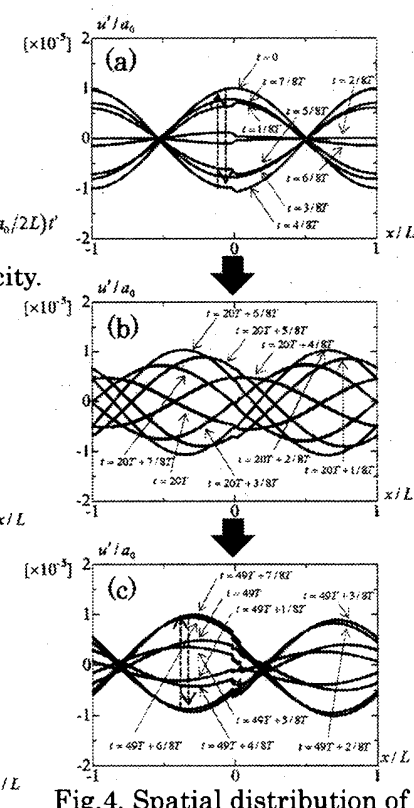

Fig.4. Spatial distribution of the axial velocity (a) $t=0 \sim T$ (b) $t=20 \sim 21 T$ (c) $t=49 \sim 50 T$.
5. 結言 熱音響式熱機関に用いられるスタック内の小さな孔 でも境界層理論が適用可能であることがわかった. また, $r_{\text {stack }}$ や $R$ を変化させたところ, Ueda \& Kato によって求められた臨界 条件と定性的に一致した．ただし，スタック外部では散逸を無 視しているので, 臨界温度比は若干低い，その後の発展では, 図 4 で示されるように初期位相を変化させても, 流速が温度勾 配の存在する場所（スタック）で小さく，一方圧力は大きくな る分布へ移行する傾向（引き込み）が確認できた．この分布は 実験結果 1) と一致しており, 境界層理論によってある程度現象 が説明できることを示している.

\section{参考文献}

(1) Y. Ueda and C. Kato, J. Acoust. Soc. Am. 124(2), 851-858 (2008).

(2) N. Sugimoto and D. Shimizu, Phys. Fluids, 20(10), 104102 (2008). 